\title{
Large-scale purification of factor VIII by affinity chromatography: optimization of process parameters
}

MARCEL P. W. M. TE BOOY, ANITA FABER, EGGE DE JONGE and ERNST P. WOLTERINK Central Laboratory of the Netherlands Red Cross Blood Transfusion Service, P.O. Box 9406, 1006 AK Amsterdam (The Netherlands)

WAANDER RIETHORST, TOM BEUGELING and ADRIAAN BANTJES

University of Twente, Department of Chemical Technology, 7500 AE Enschede (The Netherlands) and

JAN OVER and BOUDEWIJN W. KÖNIG*

Central Laboratory of the Netherlands Red Cross Blood Transfusion Service, P.O. Box 9406, 1006 AK Amsterdam (The Netherlands)

(First received July 5th, 1989; revised manuscript received October 27th, 1989)

SUMMARY

The optimization of a new process for the extraction of human coagulation factor VIII (FVIII) from plasma with the tailor-made affinity matrix dimethylaminopropylcarbamylpentyl-Sepharose CL-4B (C3-C5 matrix) is described. First, plasma is applied to DEAE-Sephadex A-50 anion exchanger in order to separate a number of proteins, including coagulation factors II, IX and X (prothrombin complex), from FVIII. Subsequently, the unbound fraction of the ion exchanger, containing FVIII, is contacted with the C3-C5 affinity matrix. Optimization of the FVIII affinity chromatographic procedure is accomplished in terms of the ligand density of the matrix, adsorption mode (batch-wise versus column-wise adsorption and matrix to plasma ratio), and conditions of $\mathrm{pH}$ and conductivity to be applied on washing and desorption. In scale-up experiments, by processing 201 of plasma, the recovery $(340 \mathrm{U}$ VIII:C/kg plasma) and the specific activity (s.a.) (1.2 U VIII:C/mg protein) are better than those obtained by cryoprecipitation (recovery $300 \mathrm{U}$ VIII:C/kg plasma, s.a. 0.3 $\mathrm{U}$ VIII:C/mg protein). The newly developed process using the specially designed C3-C5 affinity matrix has potential application in the process-scale purification of FVIII.

\section{INTRODUCTION}

Preparations of coagulation factor VIII (FVIII) and Von Willebrand factor (vWf) are used in the trcatment of patients suffcring from hacmophilia $A$ or Von Willebrand's disease. Cryoprecipitation is the technique most commonly used to recover these components from human donor plasma ${ }^{1,2}$. Unfortunately, the FVIII 
yield and specific activity (s.a.) of cryoprecipitate are usually low: only $40 \%$ of FVIII in plasma can be recovered with an s.a. of $0.3 \mathrm{U}$ factor VIII activity (VIII:C) per mg of protein. As impurities in the cryoprecipitate might cause side effects ${ }^{3,4}$, successive purification methods have been developed ${ }^{5-11}$ which yield FVIII preparations with s.a. varying from 1 to $3000 \mathrm{U}$ VIII:C/mg protein. However, high degrees of purification inevitably imply a low recovery; final recoveries of VIII:C of less then $20 \%$ are common in plasma fractionation on a full process scale. These low recoveries are mainly due to the use of cryoprecipitate as the source material for FVIII preparations with a higher purity.

Higher recoveries may be obtained when cryoprecipitation is replaced by a more efficient method. Therefore, it was investigated whether direct application of (affinity) chromatography to plasma could result in an FVIII preparation which is better in terms of recovery and degree of purification. Considering the limited availability of human donor plasma, a high recovery was of greater importance in this investigation than a high degree of purification. Further, a reproducible and controllable process is necessary to meet the good manufacturing practices (GMP) requirements set for the production of pharmaceuticals (e.g., protein) for use in humans ${ }^{12}$.

The synthesis of several affinity matrices, specially developed for isolation of FVIII directly from plasma, was reported previously ${ }^{13,14}$. One of these FVIII affinity matrices, dimethylaminopropylcarbamylpentyl-Sepharose $\mathrm{Cl}-4 \mathrm{~B}$, proved to be the most suitable for the purification of FVIII from plasma ${ }^{14}$. In this paper, results are presented concerning the optimization of a chromatographic FVIII purification procedure, with this tailor-made affinity matrix, characterized by a relatively high recovery and s.a. of FVIII.

\section{EXPERIMENTAL}

\section{Materials}

Normal plasma pools were prepared from 30-80 donations of citrate-phosphate-dextrose-adenine (CPDA-1)-anticoagulated plasma [Central Laboratory of the Netherlands Red Cross Blood Transfusion Service (CLB), Amsterdam, The

\section{TABLE I}

OVERVIEW OF BUFFERS AND THEIR COMPOSITIONS

\begin{tabular}{lllll}
\hline $\begin{array}{l}\text { Buffer } \\
\text { type }\end{array}$ & $p H$ & $\begin{array}{l}\text { [Sodium chloride] [Sodium acetate] } \\
(M)\end{array}$ & $\begin{array}{l}{[\text { L-Lysine] }} \\
(\boldsymbol{M})\end{array}$ \\
\hline $\mathrm{A}$ & 7.0 & 0.18 & & \\
$\mathrm{~B}$ & 7.0 & 2.0 & 0.1 & 0.1 \\
$\mathrm{C}$ & 7.4 & - & 0.1 & 0.1 \\
$\mathrm{D}$ & 7.4 & 1.0 & & \\
$\mathrm{E}$ & 7.4 & $X^{b}$ & & \\
$\mathrm{~F}$ & $\mathrm{Y}^{\mathrm{b}}$ & 0.17 & 0.1 & 0.1 \\
$\mathrm{G}$ & 7.4 & $Z^{b}$ & 0.1 \\
$\mathrm{H}$ & 7.4 & 0.04 & & 0.1 \\
\hline
\end{tabular}

a The buffers contained also $10 \mathrm{~m} M$ sodium citrate and $1 \mathrm{~m} M$ calcium chloride.

${ }^{b} X=0.10-0.25 M \mathrm{NaCl} ; Y=\mathrm{pH} 6-8 ; Z=0.25-1.50 M \mathrm{NaCl}$. 
Netherlands]. Human serum albumin and specific antisera against human albumin, fibronectin, fibrinogen and factor II were from the CLB. DEAE-Sephadex A-50, Sepharose CL-4B and chromatographic columns (C10/20, C16/30, C26/30, K50/30 and BP 113/30) were obtained from Pharmacia (Uppsala, Sweden). Affinity matrices with various ligand densities were obtained as described below. All chemicals were purchased from Merck (Darmstadt, F.R.G.). In Table I, an overview of the composition of the buffers used is presented.

\section{Synthesis of affinity matrix}

For synthesis of the affinity matrix, the method described by Riethorst ${ }^{13}$ was used: a known amount (settled gel volume) of Sepharose CL-4B was solvent exchanged from water to dimethylformamide (DMF) by washing the support extensively with dry DMF on a sintered-glass filter (G3). Subsequently, the support was activated $\left(1.5 \mathrm{~h}, 20^{\circ} \mathrm{C}\right)$ with $1,1^{\prime}$-carbonyldiimidazole $(\mathrm{CDI})$. The degree of activation was varied by the amount of CDI, dissolved in DMF, added to the support $(0.10-0.32$ $\mathrm{mmol} / \mathrm{ml}$ of settled gel in water). The CDI-activated support was washed with DMF and, subsequently, 6 -aminohexanoic acid was coupled $\left(20^{\circ} \mathrm{C}, 10 \mathrm{~h}\right)$ by mixing a solution of the amino acid in water $(\mathrm{pH} 12.6)$ with the gel suspension $(0.9 \mathrm{mmol}$ of the amino acid per $\mathrm{ml}$ of settled gel in water). After coupling, the gel was washed with DMF and water, the ligand density of the carboxylic acid end groups on the support was determined (see below) and the support was again solvent exchanged to DMF. Carboxylic acid end-groups were esterified $\left(20^{\circ} \mathrm{C}, 16 \mathrm{~h}\right)$ with $\mathrm{N}$-hydroxysuccinimide (4-6 times the amount of carboxylic acid groups) using an equal amount of 1-ethyl-3(3-dimethylaminopropyl)carbodiimide as a coupling agent. After washing with DMF, dimethylaminopropylamine (20 times the amount of carboxylic acid groups) was coupled onto the matrix $\left(20^{\circ} \mathrm{C}, 16 \mathrm{~h}\right)$. After solvent exchange to water, the density of the dimethylaminopropylcarbamylpentyl (C3-C5) ligands on the affinity support was determined (see below). Finally, C3-C5 affinity matrices were obtained with various ligand densities $(40-100 \mu \mathrm{mol} / \mathrm{ml}$ of settled wet gel). The structure of the affinity matrix (C3-C5 matrix) is shown in Fig. 1.

Assays

Ligand densities of affinity matrices ( $\mu$ moles of amine per $\mathrm{ml}$ of settled wet gel volume) were calculated from the hydrochloric acid titration curve of the sodium hydroxide equilibrated matrix ${ }^{15}$. FVIII activity (VIII:C) was determined in a chromogenic substrate assay (Coatest factor VIII, KabiVitrum, Stockholm, Sweden). FVIII and vWf protein concentrations [factor VIII antigen (VIII:Ag) and vWf antigen (vWf:Ag), respectively] were determined in sandwich enzyme-linked immunosorbent assays (ELISAs) using monoclonal antibodies directed against factor VIII (CLB-CAg-A and CLB-CAg-117) and vWf (CLB-RAg-20 and CLB-RAg-35), respectively. Coagulation factors II, VII, IX and X were determined with assays ${ }^{16-18}$

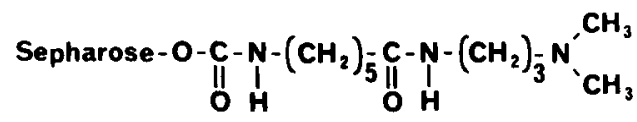

Fig. 1. Structure of the C3-C5 affinity ligand. 
using artificial substrate plasmas for FII and FX, congenitally deficient substrate plasma for VFII and immunodepleted substrate plasma for FIX determination. The vWf multimeric structure was analysed using agarose gel electrophoresis ${ }^{19}$.

The $\mathrm{vWf}$ activity [vWf-associated ristocetin cofactor activity (vWf:RCo)] was determined by ristocetin-induced agglutination of washed platelets ${ }^{20}$. A normal plasma pool, calibrated against 30 normal plasmas, was used as a standard in all assays for coagulation factors, vWf: RCo and vWf:Ag. Traces of thrombin, if present, were determined by adding a $0.3 \%(\mathrm{w} / \mathrm{w})$ fibrinogen solution (KabiVitrum) to an equal volume of sample. One mixture was incubated for $20 \mathrm{~h}$ at $24^{\circ} \mathrm{C}$ and one for $6 \mathrm{~h}$ at $37^{\circ} \mathrm{C}$. After incubation, the mixtures were checked for fibrin formation. Albumin, IgG, IgA and IgM were determined in a nephelometer analyser (Behring, Marburg, F.R.G.). Fibrinogen, fibronectin and factor II antigen concentrations were determined by single radial immunodiffusion ${ }^{21}$, using specific antisera (CLB). $\mathrm{C}_{1}$-esterase inhibitor activity was determined in a chromogenic substrate assay (Behrichrom, Behring, R.R.G.). Total protein content was determined with the BCA-protein assay (Pierce, Rockford, IL, U.S.A.), using purified human serum albumin (CLB) as a protein standard.

\section{Chromatographic procedures}

Batch-wise adsorption of plasma proteins onto the DEAE-Sephadex A-50 ion exchanger was achieved by adding various amounts of plasma to the pre-swollen matrix [26.7 $\mathrm{g}$ of dry ion exchanger per litre of $0.9 \%(\mathrm{w} / \mathrm{v})$ sodium chloride]. The adsorption was carried out for $15-90 \mathrm{~min}$ at $15^{\circ} \mathrm{C}$. After separation of the anion exchanger from the plasma using 20- $\mu$ m netting (Type NY-20-hc, ZBF, Rueschlikon, Switzerland), the ion exchanger was suspended in buffer A (Table I) and poured into a chromatographic column. After settling of the gel, the anion exchanger was washed with buffer A at a flow-rate of $24 \mathrm{~cm} / \mathrm{h}$. Proteins, such as FII, FIX and FX, were desorbed from the DEAE-Sephadex by elution, at the same flow-rate, with four column volumes of buffer B (Table I).

Batch-wise adsorption of plasma proteins onto the C3-C5 matrices was achieved by "end-over-end" mixing of at least $2 \mathrm{ml}$ (wet gel volume) of equilibrated matrix (buffer E, Table I, $x=175 \mathrm{mM}$ ) with various amounts of plasma. Adsorption times varied from $5 \mathrm{~min}$ to $6 \mathrm{~h}$ (adsorption temperature $20^{\circ} \mathrm{C}$ ). The $\mathrm{C} 3-\mathrm{C} 5$ matrix, separated from the supernatant plasma by centrifugation $(3 \mathrm{~g}, 5 \mathrm{~min})$, was transferred to a column and after settling the gel was washed (3-6 bed volumes) and proteins (e.g., FVIII) were eluted $(6-10$ bed volumes) at a flow-rate of $30-60 \mathrm{~cm} / \mathrm{h}$. For the buffers applicd, sce Results. For column-wisc adsorption, the C3-C5 matrix was packed under pressure $(0.15 \mathrm{bar})$ and equilibrated with buffer $\mathrm{E}$ (Table $\mathrm{I}, x=175$ $\mathrm{m} M$ ). Fresh thawed plasma (volume 18-35 times the bed volume) was incubated batch-wise for $60 \mathrm{~min}$ at $15^{\circ} \mathrm{C}$ with preswollen DEAE-Sephadex A-50 $(0.5 \mathrm{~g}$ of ion exchanger per kg of plasma). After filtration (0.5- $\mu \mathrm{m}$ filter, Profile type R 1 fo05; Pall, Portsmouth, U.K.), the filtrate was applied to the affinity matrix at a flow-rate of 30 $\mathrm{cm} / \mathrm{h}$. After protein adsorption, the matrix was washed with 3-6 column volumes of buffer E (Table I, $x=175 \mathrm{mM}$ ) and proteins were desorbed by elution with 5-10 column volumes of buffer $\mathrm{D}$ (Table I) at the same flow-rate. The desorption fraction of the C3-C5 matrix was concentrated and dialysed against buffer H (Table II) using a haemodialysis cartridge with a cut-off of 100000 (type HF 40; Fresenius, Bad Homburg, F.R.G.). 


\section{TABLE II}

\section{BATCH-WISE VERSUS COLUMN-WISE ADSORPTION OF FVIII ONTO THE C3-C5 MATRIX}

Pretreated plasma is adsorbed onto the $\mathrm{C} 3-\mathrm{C} 5$ matrix (ligand density $90 \mu \mathrm{mol} / \mathrm{ml}$ ), column-wise washing with six bed volumes of buffer type $C$ (see Table I), flow-rate $30-60 \mathrm{~cm} / \mathrm{h}$. Column-wise desorption with ten bed volumes of buffer type D, flow-rate $30 \mathrm{~cm} / \mathrm{h}$.

\begin{tabular}{|c|c|c|c|c|c|}
\hline \multirow{2}{*}{$\begin{array}{l}\text { Adsorption } \\
\text { type }\end{array}$} & \multirow{2}{*}{$\begin{array}{l}\text { Time } \\
(\min )\end{array}$} & \multirow{2}{*}{$\begin{array}{l}\text { G:P ratio } \\
(v / v)\end{array}$} & \multicolumn{2}{|l|}{ FVIII } & \multirow{2}{*}{$\begin{array}{l}\text { Protein } \\
\text { desorbed } \\
(\%)\end{array}$} \\
\hline & & & $\begin{array}{l}\text { Adsorbed } \\
(\%)\end{array}$ & $\begin{array}{l}\text { Desorbed } \\
(\%)\end{array}$ & \\
\hline \multirow[t]{4}{*}{ Batch } & 60 & $1: 20$ & $>95$ & 61 & 0.3 \\
\hline & 60 & $1: 25$ & 85 & 55 & 0.3 \\
\hline & 60 & $1: 30$ & 75 & 45 & 0.3 \\
\hline & 360 & $1: 20$ & $>95$ & 51 & 0.4 \\
\hline \multirow[t]{6}{*}{ Column } & 70 & $1: 20$ & $>95$ & 69 & 0.5 \\
\hline & 220 & $1: 20$ & $>95$ & 61 & 0.5 \\
\hline & 360 & $1: 20$ & $>95$ & 51 & 0.5 \\
\hline & 450 & $1: 25$ & $>95$ & 49 & 0.5 \\
\hline & 540 & $1: 30$ & $>95$ & 51 & 0.5 \\
\hline & 630 & $1: 35$ & $>95$ & 35 & 0.4 \\
\hline
\end{tabular}

${ }^{a} \mathrm{G}: \mathrm{P}$ ratio is the ratio $(\mathrm{v} / \mathrm{v})$ of $\mathrm{C} 3-\mathrm{C} 5$ matrix to plasma pretreated with $0.5 \mathrm{~g}$ of dry DEAE-Sephadex A. 50 per $\mathrm{kg}$ of plasma.

\section{RESULTS}

\section{Separation of coagulation factors $I I, I X$ and $X$ from factor VIII}

Under conditions such that FVIII is completely absorbed onto the C3-C5 matrix, other coagulation factors (II, IX and X) are simultaneously absorbed from plasma ${ }^{14}$. Therefore, in order to separate FII, FIX and FX from FVIII, an additional ion-exchange step with DEAE-Sephadex A-50 was introduced prior to adsorption of proteins onto the $\mathrm{C} 3-\mathrm{C} 5$ matrix. Fig. 2 shows the time-dependent kinetics of ad-

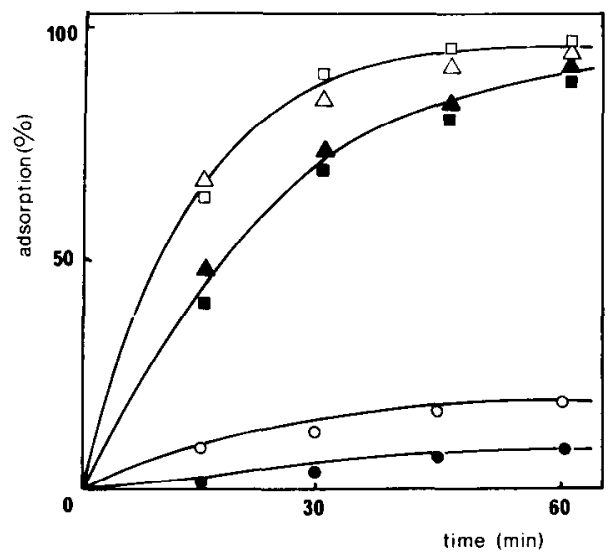

Fig. 2. Time-dependent adsorption of coagulation factors II ( $\square$ ), VIII (O) and IX ( $\triangle$ ) from normal plasma onto DEAE-Sephadex A-50 at ratios of 0.75 (open symbols) and 0.50 (solid symbols) of dry DEAE-Sephadex A-50 per $\mathrm{kg}$ of plasma. Batch-wise adsorption at $15^{\circ} \mathrm{C}$. 


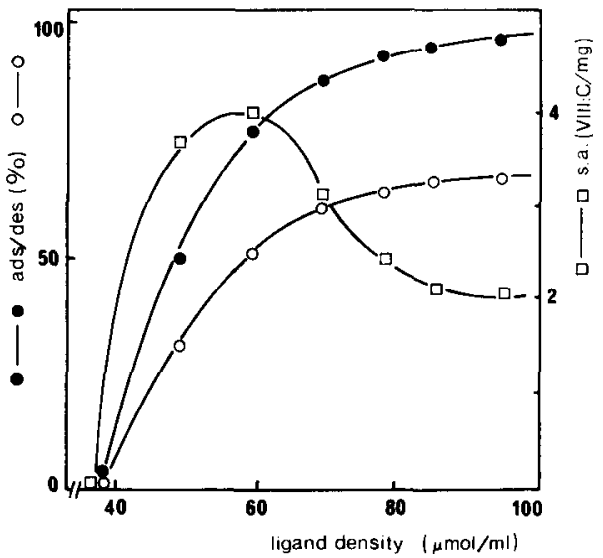

Fig. 3. Adsorption (O) and desorption $(O)$ of VIlI:C from the C3-C5 matrix and specific activity (s.a.) ( $\square$ ) of desorbed VIII:C as a function of the ligand density of the affinity matrix. Batch-wise incubation for $1 \mathrm{~h}$ of $30 \mathrm{ml}$ of plasma, pretreated with $0.5 \mathrm{~g}$ of dry DEAE-Sephadex A-50 per $\mathrm{kg}$ of plasma and $2 \mathrm{ml}$ of C3-C5 matrix. Column-wise washing with $12 \mathrm{ml}$ of buffer type C (see Table I) at a flow-rate of $60 \mathrm{~cm} / \mathrm{h}$. Column-wise desorption with $20 \mathrm{ml}$ of buffer type $\mathrm{D}$ at a flow-rate of $30 \mathrm{~cm} / \mathrm{h}$ at $20^{\circ} \mathrm{C}$.

sorption of coagulation factors II, VIII and IX onto the DEAE-Sephadex A-50 anion exchanger at two different ratios of anion exchanger to plasma $(0.5$ and $0.75 \mathrm{~g}$ of dry DEAE-Sephadex A-50 per kg of plasma). As the adsorption kinetics of FIX and FX are essentially the same, only the ad-/desorption data for FIX are presented. Fig. 2 shows that an optimum separation of FVIII from FII and FIX can be obtained by using an incubation time of $60 \mathrm{~min}$ at a ratio of $0.5 \mathrm{~g}$ of anion exchanger per $\mathrm{kg}$ of plasma. Under these conditions, $>90 \%$ of the coagulation factors II and IX are removed hy adsorption onto the anion exchanger at the cost of a $10-15 \%$ loss of VIII:C in the unbound fraction. Plasma pretreated with DEAE-Sephadex A-50, as described above, is used as the starting material for the purification of FVIII by means of the C3-C5 affinity matrix.

\section{Effect of ligand density of the C3-C5 matrix on purification of FVIII}

Results of batch-wise adsorption experiments with DEAE-Sephadex A-50 pretreated plasma (Fig. 3) show that a minimum ligand density $(>40 \mu \mathrm{mol} / \mathrm{ml})$ is required for adsorption of FVIII onto the $\mathrm{C} 3-\mathrm{C} 5$ matrix. For complete adsorption of FVIII (in $60 \mathrm{~min}$ at a gel-to-plasma ratio of $1: 20, \mathrm{v} / \mathrm{v}$ ), a ligand density of $>80$ $\mu \mathrm{mol} / \mathrm{ml}$ is necessary. The total protein ad-/desorption increases linearly with an increase in ligand density (results not shown). The optimum result with respect to recovery and s.a. of desorbed FVIII is obtained in the range $80-90 \mu \mathrm{mol} / \mathrm{ml}: 60 \%$ of FVIII is recovered, with an s.a. of $1.8 \mathrm{U}$ VIII:C/mg protein (Fig. 3).

\section{Effect of the composition of wash and desorption buffers on FVIII purity}

Varying the $\mathrm{pH}$ of the wash buffer between $\mathrm{pH} 6$ and 8 shows that an optimum with respect to FVIII and protein recovered in the desorption fraction is reached between $\mathrm{pH} 7.0$ and 7.5 (Fig. 4A). Increasing the sodium chloride concentration in the wash buffer from 100 to $250 \mathrm{mM}$ results in a linear decrease in the amount of 


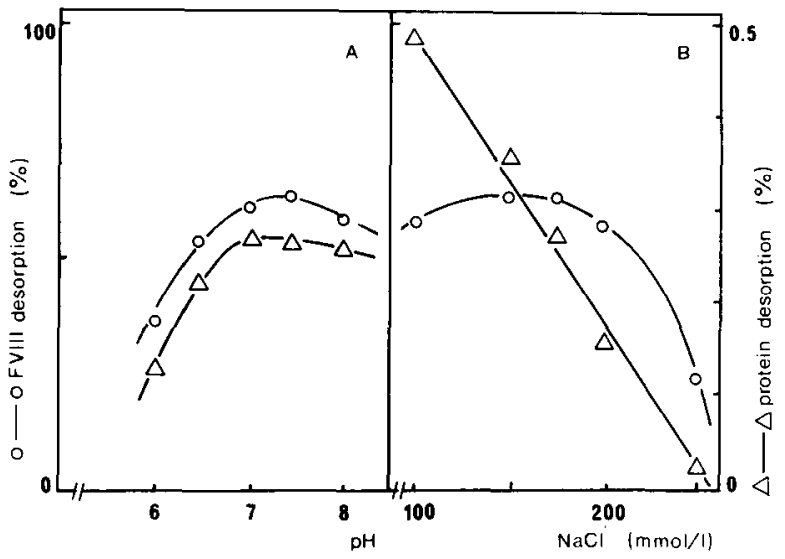

Fig. 4. Effect of (A) $\mathrm{pH}$ and (B) $\mathrm{NaCl}$ concentration of wash buffer on desorption of VIII:C (O) and protein $(\triangle)$ from the $\mathrm{C} 3-\mathrm{C} 5$ matrix. Batch-wise incubation for $1 \mathrm{~h}$ of $30 \mathrm{ml}$ of plasma (pretreated with $0.5 \mathrm{~g}$ dry of DEAE-Sephadex A-50 per $\mathrm{kg}$ of plasma), $2 \mathrm{ml}$ of C3-C5 matrix (ligand density $90 \mu \mathrm{mol} / \mathrm{ml}$ ); column-wise washing with $12 \mathrm{ml}$ of buffer type F (A) or type E (B) (see Table I) at a flow-rate of $60 \mathrm{~cm}$. Column-wise desorption with $20 \mathrm{ml}$ of buffer type $\mathrm{D}$ at a flow-rate of $30 \mathrm{~cm} / \mathrm{h}$ at $20^{\circ} \mathrm{C}$.

protein desorbed; an optimum in terms of recovery of desorbed FVIII and effective removal of contaminating proteins by salt washing is obtained at a sodium chloride concentration between 150 and $175 \mathrm{mM}$ (Fig. 4B). Fig. 5 shows that the optimum concentration of sodium chloride to be used in the desorption buffer, in terms of the maximum amount of desorbed VIII:C in combination with a minimum of total desorbed protein, is in the range $0.75-1.25 \mathrm{M}$.

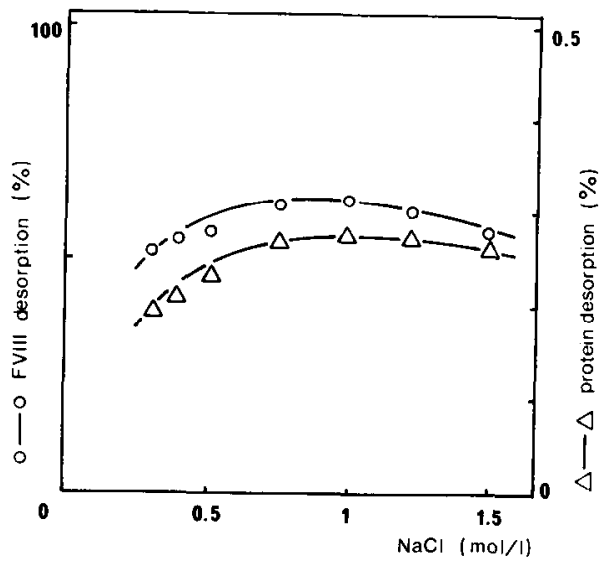

Fig. 5. Effect of $\mathrm{NaCl}$ concentration in the elution buffer on desorption of VIII:C $(O)$ and protein $(\Delta)$ from the C3-C5 matrix. Batch-wise incubation for $1 \mathrm{~h}$ of $30 \mathrm{ml}$ of plasma (pretreated with $0.5 \mathrm{~g}$ of DEAE-Sephadex A-50 per kg of plasma), $2 \mathrm{ml}$ of C3-C5 matrix (ligand density $90 \mu \mathrm{mol} / \mathrm{ml}$ ); column-wise washing with $12 \mathrm{ml}$ of buffer type $\mathrm{E}, X=0.17$ (see Table 1 ), at a flow-rate of $60 \mathrm{~cm} / \mathrm{h}$. Column-wise desorption with $20 \mathrm{ml}$ of buffer type $\mathrm{G}$ at a flow-rate of $30 \mathrm{~cm} / \mathrm{h}$ at $20^{\circ} \mathrm{C}$. 
Batch-wise versus column-wise adsorption of FVIII

The data in Table II indicate that a decrease in the matrix-to-plasma ratio at a constant batch-wise incubation time $(1 \mathrm{~h})$ results in a reduction in the amount of adsorbed and desorbed FVIII. The amount of desorbed total protein, however, is not affected by the matrix-to-plasma ratio. The ratio of $1: 20$ for the latter is the minimum applicable under these conditions. Prolongation of the incubation time from 60 to 360 min results in a decrease in the amount of FVIII desorbed, whereas the amount of protein desorbed is slightly increased. 'The results of the column-wise adsorption of FVIII reveal that an extension of the contact time, by increasing the bed height of the column, or an increase in the amount of plasma applied to the matrix has an adverse effect on the amount of desorbed FVIII, whereas the amount of total protein desorbed is not affected.

\section{Scaling up of FVIII purification process}

Batch-wise adsorption and column-wise desorption experiments were scaled up from an initial gel volume of $2 \mathrm{ml}$ up to $200 \mathrm{ml}$. Column-wise adsorption and desorption experiments were scaled up from $10 \mathrm{ml}$ to a gel volume of $1000 \mathrm{ml}$. In all experiments, plasma pretreated with DEAE-Sephadex A-50 was used as the FVIII source. The amount of plasma applied was usually 15-25 times the gel volume. Prior to column-wise adsorption, the starting material was filtered. Results of scale-up experiments (Table III) show that the FVIII recovery and the amount of total protein desorbed from the C3-C5 matrix are independent of scale size.

\section{Characterization of FVIII concentrate}

The FVIII concentrate, obtained from concentration and dialysis of the eluate of the C3-C5 matrix, contained $35 \mathrm{U}$ VIII:C/ml with a specific activity of $1.2 \mathrm{U}$ VIII:C/mg protein. Analysis of vWf:RCo, vWf:Ag and FVIII:Ag revealed (see Table IV) that the VIII:C/VIII:Ag, VIII:C./VWF:RCo and $\mathrm{vWf:RCo/vWf:Ag} \mathrm{ratios} \mathrm{are}$

\section{TABLE III}

SCALING UP OF PROCESS PARAMETERS FOR FVIII PURIFICATION FROM PLASMA WITH THE C3-C5 AFFINITY MATRIX

Adsorption from plasma (pretreated with $0.5 \mathrm{~g}$ of dry DEAE-Sephadex A-50 per $\mathrm{kg}$ of plasma) onto C3-C5 matrix (ligand density $90 \mu \mathrm{mol} / \mathrm{ml}$ ), batch-wise adsorption in $1 \mathrm{~h}$, column-wise adsorption at a flow-rate of $30 \mathrm{~cm} / \mathrm{h}$. Column-wise washing with six bed volumes of buffer type $\mathrm{C}$ (see Table I), flow-rate $30-60 \mathrm{~cm} / \mathrm{h}$. Column-wise desorption with ten bed volumes of buffer type D, flow-rate $30 \mathrm{~cm} / \mathrm{h}$.

\begin{tabular}{rrrrr}
$\begin{array}{l}\text { C3-C5 matrix } \\
(m l)\end{array}$ & $\begin{array}{l}\text { Plasma } \\
(\mathrm{ml})\end{array}$ & $\begin{array}{l}\text { Factor VIII } \\
\text { recovery }(\%)^{a}\end{array}$ & $\begin{array}{l}\text { Protein } \\
\text { recovery }(\%)^{a}\end{array}$ & $\begin{array}{l}\text { Process time } \\
(h)\end{array}$ \\
\hline 2 & 30 & 57 & 0.30 & 2 \\
10 & 200 & $58(55)$ & $0.30(0.53)$ & $2(9)$ \\
20 & 400 & $61(51)$ & $0.31(0.49)$ & $5(9)$ \\
100 & 2000 & $52(57)$ & $0.33(0.40)$ & $5(8)$ \\
200 & 4000 & $(56)$ & $(0.50)$ & $(11)$ \\
1000 & 20000 & $(52)$ & $(0.46)$ & $(11)$ \\
\hline
\end{tabular}

${ }^{a}$ Recovery compared with the amount in plasma. Data in parentheses are for column-wise adsorption and desorption. 


\section{TABLE IV}

CHARACTERIZATION OF FVIII CONCENTRATE ISOLATED BY AFFINITY PURIFICATION WITH C3-C5 MATRIX

\begin{tabular}{lll}
\hline Protein & Amount per $m l$ & Recovery $(\%)^{a}$ \\
\hline VIII:C & $35 \mathrm{U}$ & 46 \\
VIII:Ag & $42 \mathrm{U}$ & 55 \\
vWf:RCo & $40 \mathrm{U}$ & 50 \\
vWf:Ag & $44 \mathrm{U}$ & 55 \\
Fibronectin & $5.2 \mathrm{mg}$ & \\
Fibrinogen & $5.0 \mathrm{mg}$ & \\
Prothrombin & $0.6 \mathrm{mg}$ & \\
IgG & $1.2 \mathrm{mg}$ & \\
IgA & $0.3 \mathrm{mg}$ & \\
IgM & $3.2 \mathrm{mg}$ & \\
Albumin & $3.2 \mathrm{mg}$ & \\
Total protein & $29 \mathrm{mg}$ & \\
\hline
\end{tabular}

a Recovery relative to starting plasma.

close to unity. Further, the vWf multimeric pattern of the concentrate (data not shown) is the same as that of the starting plasma. In addition to FVIII and vWf, fibronectin, fibrinogen, IgM, albumin and trace amounts of IgG, IgA and FII were present in the FVIII concentrate (Table IV). These contaminants constitute about $70 \%$ of the total amount of protein present. Under the conditions used, neither FVII nor $\mathrm{C}_{1}$-esterase inhibitor adsorbed onto the C3-C5 matrix.

\section{DISCUSSION}

\section{Separation of coagulation factors $I I, I X$ and $X$ from factor VIII}

Similarly to the use of FVIII concentrates in the treatment of haemophilia A, FIX concentrates are applied for treatment of haemophilia B patients. Commonly FIX concentrates are prepared by ion-exchange chromatography of the supernatant plasma after cryoprecipitation ${ }^{2-24}$. Since FVIII and FIX, present in plasma, both adsorb onto the C3 C5 matrix and are difficult to separate by means of step-wise sodium chloride elution ${ }^{14}$, an additional separation step is needed when both FVIII and FIX concentrates are to be produced. For this purpose, ion-exchange chromatography with DEAE-Scphadex A-50 was implemented prior to application of the plasma onto the C3-C5 matrix. At DEAE-Sephadex-to-plasma ratios of $0.5-0.75$ (g dry DEAE-Sephadex per kg plasma), both FII and FIX are removed from plasma relatively fast (Fig. 2). The similarity in the adsorption behaviour of these coagulation factors was also observed by Heystek et al. ${ }^{23}$. Under these conditions, the adsorption of FVIII is much slower, and the loss of FVIII during the 60 -min incubation is limited to $10-15 \%$. Differences in adsorption rate of FII, FIX and FVIII, at low ratios of ion exchanger to plasma, are probably due to the large size difference between FIX and FII $\left(M_{\mathrm{r}}<1 \cdot 10^{5} \mathrm{kDa}\right)$ on the one hand and FVIII, which is complexed to $\mathrm{VWf}\left(M_{\mathrm{r}}\right.$ $\left.>1.10^{6} \mathrm{kDa}\right)$, on the other. The size of the protein not only affects the diffusion rate but also excludes the larger proteins from penetration into the smaller pores of the ion 
exchanger. At a ratio of $0.5 \mathrm{~g}$ of DEAE-Sephadex A-50/kg pf plasma, an effective separation between FIX and FVIII is oblained in $1 \mathrm{~h}$. FIX is adsorbed to the extent of $>90 \%$ whereas FVIII adsorption is less than 15\%. Although FVIII adsorption in this step means a direct loss, the overall recovery after desorption from the C3-C5 matrix $(57 \%$, Table III) is only slightly lower than that with normal plasma when directly contacted with the C3-C5 matrix and eluted therefrom $\left(62 \%{ }^{14}\right)$. An additional advantage of treatment of plasma with DEAE-Sephadex A-50, prior to adsorption onto the $\mathrm{C} 3-\mathrm{C} 5$ matrix, is that the binding capacity for FVIII on the $\mathrm{C} 3-\mathrm{C} 5$ matrix is increased from $10 \mathrm{U}$ VIII:C/ml gel ${ }^{14}$ to $16 \mathrm{U}$ VIII:C/ml gel (ligand density $90 \mu \mathrm{mol} / \mathrm{ml}$ ). Further, the s.a. of desorbed FVIII is improved from $1.2 \mathrm{U}$ VIII:C/mg protein ${ }^{14}$ to $2.1 \cup$ VIII:C/mg protein. The s.a. of the FIX preparation eluted from DEAE-Sephadex A-50 (recovery $55 \%$ ) is $2.5 \mathrm{U}$ FIX/mg protein. Owing to the low ratio of DEAE-Sephadex A-50 to plasma, this s.a. of FIX is better than that for preparations obtained by reported procedures (1.0-1.5 U FIX/mg protein ${ }^{22-24}$ ).

\section{Effect of ligand density}

For the determination of the optimum ligand density of the C3-C5 matrix, a compromise is made between s.a., adsorption time, economics and recovery. Compared with high ligand densities, the lower ligand densities give a higher s.a. at lower yields (Fig. 3) and need longer adsorption times and/or higher matrix-to-plasma ratios (data not shown). As a matrix-to-plasma ratio of 1:20 (v/v) is considered to be the maximum for production purposes, a ligand density of $90 \mu \mathrm{mol} / \mathrm{ml}$ is required to give fast and complete adsorption of FVIII. At this ligand density, the s.a. of desorbed FVIII still meets our goals. It is remarkable that, independent of the ligand density applied, the ratio of desorbed to adsorbed FVIII is a constant factor $(0.65)$. This sets clear limits to the maximum recovery of FVIII in this type of chromatographic process step. Nevertheless, this result is better than that with chromatography of FVIII on aminohexyl-Sepharose, where a ratio of $<0.50$ is found ${ }^{25,26}$.

\section{Effect of composition of the wash and desorption buffer}

Because the developed purification method for FVIII described is for processscale chromatography, the compositions of the buffers are kept relatively simple. Variations in $\mathrm{pH}(6.0-8.0)$ and sodium chloride concentration $(100-1500 \mathrm{mM})$ in the buffers are limited owing to the lability of FVIII. The optimum sodium chloride concentration in the wash buffer is $170 \mathrm{mM}$; higher sodium chloride concentrations result in desorption of FVIII and at lower concentrations removal of contaminating proteins is not as effective. The optimum $\mathrm{pH}$ of the wash buffer in combination with a sodium chloride concentration of $170 \mathrm{mM}$ is 7.4. At higher $\mathrm{pH}$ the FVIII is less stable, resulting in denaturation of FVIII, and at lower $\mathrm{pH}$ more protein, including FVIII, is washed from the matrix. These results arc in accordance with results obtained with aminohexyl-Sepharose ${ }^{25,26}$. Variation of the sodium chloride concentration in the desorption buffer had a minor effect on the s.a. of FVIII. As the desorption of FVIII is tailing at low sodium chloride concentration, a sodium chloride concentration in the desorption buffer of $1 M$ is used as an optimum concentration with respect to FVIII recovery. 
Batch-wise versus column-wise adsorption of FVIII and scaling up of process parameters for FVIII purification

The results in Table II show that batch-wise and column-wise adsorption (same adsorption time) differ mainly in the total amount of protein (adsorbed and) desorbed. There are also differences in the final FVIII recovery, but these seem to be caused by the longer process time and are independent of the adsorption principle. For the choice of the adsorption mode to be applied on a production scale, where plasma volumes of 750-1000 1 are processed, not only aspects such as recovery and purity are important parameters, but also whether the process meets GMP requirements $^{12}$. From the latter point of view, it may be clear that a batch-wise adsorption process, despite its higher recovery and purity, is not to be preferred. Therefore, column-wise adsorption is chosen as the adsorption mode for further scaling up. This choice has an impact on the process time. As the maximum flow-rate is not limited by the adsorption kinetics of FVIII, it is determined by the maximum flow-rate at which the C3-C5 matrix, i.e., Sepharose CL-4B, can be operated. A bed height of $10 \mathrm{~cm}$, which can still be used on a process scale, and a sample volume of 20 column volumes results in an adsorption time of 6-7 h. Scaling up experiments with the C3-C5 matrix (Table III) show that despite the long process time for column-wise adsorption and desorption, the FVIII recovery is $>50 \%$ and the purity of the eluate is $>1 \mathrm{U}$ VIII:C/ $\mathrm{mg}$ protein. These parameters are independent of the process scale, which offers good prospects for further scaling up.

\section{Characterization of FVIII concentrate}

The overall recovery after concentration and dialysis of the eluate of the $\mathrm{C} 3-\mathrm{C} 5$ matrix is $46 \%$, which is an improvement over the FVIII preparations obtained by cryoprecipitation, where recoveries of $40 \%$ are common ${ }^{3}$. The s.a. of the concentrate is $>1.0 \mathrm{U}$ VIII:C/mg protein, which is higher than that obtained with cryoprecipitation (0.3 U VIII:C/mg protein) and comparable to the s.a. of common intermediate-pure FVIII concentrates, prepared from cryoprecipitate at a much lower $(>20 \%)$ FVIII recovery ${ }^{3}$. The quality of the concentrated FVIII preparation is good as the VIII:C-to-VIII:Ag ratio is close to unity, indicating that the amount of inactive FVIII is low. The same holds true for the $\mathrm{vWf}$ RCo-to-vWf:Ag ratio, indicating that all $\mathrm{vWf}$ present in the concentrate is active. The FVIII-to-vWf ratio is also 1.0 , which is favourable for preservation of VIII:C as FVIII is stabilized by vWf. In comparison with common intermediate-pure FVIII concentrates, these data are better, as in most of these concentrates the VIII:C-to-VIII:Ag and vWf:Rco-to-vWf:Ag ratios are $<1.0$ and the IVVIII-to-vWf ratio is $>1.0^{27}$. The presence of high-molecular-weight multimers of vWf in the FVIII concentrate implies that this preparation, in contrast to other FVIII concentrates, can also be of use in the treatment of von Willebrand's disease.

\section{CONCLUSION}

With the purification method described, an FVIII concentrate can be obtained with a high yield and a relatively high yield and a relatively high s.a. as compared with cryoprecipitation. The process can meet GMP requirements, is reproducible and has the potential for automation. The implementation of the FVIII purification method 
into the fractionation of plasma has no negative effects on the purification of FIX (prepared from the DEAE-Sephadex A-50 desorption fraction), FVII and $\mathrm{C}_{1}$-esterase inhibitor, albumin and immunoglobulins which are present in the unbound fraction of the $\mathrm{C} 3 \mathrm{C} 5$ affinity matrix. Therefore, this affinity chromatographic method for FVIII purification from plasma has great potential for replacing cryoprecipitation. Further optimization of the method will be carried out with respect to reduction of the process time of elimination of blood-borne viruses, such as human immunodeficiency virus (HIV), hepatitis B virus and hepatitis non-A, non-B virus ${ }^{3}$.

\section{ACKNOWLEDGEMENTS}

We thank Miss J. Brummel and Miss B. V. Driessen for technical assistance and Dr. H. Hiemstra for critically reading the manuscript.

\section{REFERENCES}

1 J. G. Pool, E. J. Hershgold and A. R. Pappenhagen, Nature (London), 203 (1964) 312.

2 J. G. Pool and A. E. Shannon, New Engl. J. Med., 273 (1965) 1443.

3 H. R. Roberts and B. G. Macik, in M. Verstraete, J. Vermeylen, R. Lijnen and J. Arnout (Editors), Thrombosis and Haemostasis 1987, Leuven University Press, Leuven, 1987, p. 563.

4 M. N. Lederman, C. Saunders, Z. Toosi, N. Lemon, B. Everson and O. D. Ratnoff, J. Lab. Clin. Med., 107 (1986) 471.

5 J. Margolis, C. M. Gallovich and P. Rhoades, Vox Sang., 46 (1984) 341.

6 K. M. Brinkhous, E. Shanbrom, H. R. Roberts, W. P. Webster, L. Fekete and R. H. Wagner, J. Am. Med. Assoc., 205 (1968) 613.

7 J. Newman, A. J. Johnson, S. Karpatkin and S. Puszkin, Br. J. Haematol, 2 (1971) 1.

8 C. A. Fulcher and T. S. Zimmerman, Proc. Natl. Acad. Sci. U.S.A., 79 (1982) 1648.

9 V. S. Hornsey, B. D. Griffin, D. S. Pepper, L. R. Micklem and C. V. Prowse, Thromb. Haemostas., 57 (1987) 102.

10 M. Griffith, S. Liu, G. Neslund, I. Tsang, D. Lettelier and R. Berkebile, Thromb. Haemostas., 58 (1987) 307.

11 P. A. Miescher and E. R. Jaffe (Editors), Semin. Hematol., 25 Suppl. 1 (1988) 1-45.

12 G. Auterhoff, Pharm. Ind., 50 (1988) 209.

13 W. Riethorst, Ph. D. Thesis, Technical University, Twente, 1988.

14 M. P. W. M. te Booy, W. Riethorst, A. Faber, J. Over and B. W. König, Thromb. Haemostas., 61 (1989) 234.

15 E. A. Peterson and H. A. Sober, J. Am. Chem. Soc., 78 (1956) 751.

16 J. J. Veltkamp, E. F. Drion and E. A. Loeliger, Thromb. Diath. Haemorrh., 19 (1968) 279.

17 K. W. E. Denson, Acta Haematol., 15 (1961) 105.

18 R. Biggs, Human Blood Coagulation, Haemostasis and Thrombosis, Blackwell, Oxford, 2nd edn., 1976.

19 Z. Ruggeri and T. S. Zimmerman, J. Clin. Invest., 65 (1980) 1318.

20 H. J. Weiss, J. Rogers and H. Brand, J. Clin. Invest., 52 (1973) 2697.

21 G. Mancini, A. O. Carbonara and J. F. Heremans, Immunochemistry, 2 (1965) 235.

22 S. M. Middleton, I. H. Bennett and J. K. Smith, Vox Sang., 24 (1973) 441.

23 J. Heystek, H. G. J. Brummelhuis and H. W. Krijnen, Vox Sang., 25 (1973) 113.

24 L. Pejaudier, V. Kichenin-Martin, M. C. Boffa and M. Steinbuch, Vox Sang., 52 (1987) 1.

25 D. E. G. Austen, Br. J. Haematol., 43 (1979) 669.

26 A. Faure, M. Caron and D. Tepenier, J. Chromatogr., 257 (1983) 387.

27 A. Yoshioka, M. Shima, M. Nishino, N. Yoshikawa and H. Fukui, Drug Res., 37 (1987) 753. 